\title{
Value Relevance of Corporate Governance Disclosure in Annual Reports: Evidence from Listed Banks in Kenya
}

\author{
Dr. Gitahi J., PhD \\ Chandaria School of Business \\ United States International University-Africa, Nairobi, Kenya
}

Doi:10.19044/esj.2019.v15n34p273 URL:http://dx.doi.org/10.19044/esj.2019.v15n34p273

\begin{abstract}
This study investigates the value-relevance corporate governance disclosures published in the narrative part of annual reports of ten banks listed at the Nairobi Securities Exchange (NSE) over the entire period from year 2010 to year 2015. This work extends the line of research on value relevance by quantifying narrative accounting, in this case corporate governance disclosures using content analysis. In addition, in line with prior studies, this study employs the Ohlson's (1995) value-relevance model and finds that corporate governance disclosure is significantly positively related to market value, measured by the average market price per share. The findings reveal that corporate governance disclosures influence investors' perceptions and are therefore, vital to be included in annual reports, which are a major communication tool.
\end{abstract}

Keywords: Value Relevance, Market Price Per Share, Corporate Governance Disclosure, Non-Financial Disclosure

\section{Introduction}

Accounting information in a firm's annual reports shows the firm's economic status. Weygandt, Kieso and Kimmel (2003) observe that accounting information can be financial or non-financial. IASB (2011) defines financial information as information about a reporting entity's financial condition included in the IAS 1 description of financial statements. Nonfinancial information is any information that does not have to be included in the IAS 1 description of financial statements (Ronnie, 2009). Non-financial information may not be expressed in numbers or financial figures and it can have financial-statement relation or not (Thomas, Céline \& Ludwig, 2014).

Traditionally, firms' annual reports mainly included financial statements and financial information has always been one of the key building 
blocks of a firm's reporting (O'Regan, 2008). However, players in accounting have increasingly expressed concerns regarding the content of traditional accounting reporting (Amir \& Lev, 1996). Today, firms more and more rely not just on their resources but also on the resources belonging to the society. Therefore, the value creation process is based on the principle of shared costs. The value created by an organization therefore needs to be shared between its owners and society. Quality reporting by firms is therefore progressively vital for strong and sustainable organizations, financial markets, and economies (Stewart, 2015).

Regulators and standard setters are seen as an appropriate solution to solve these problems, pushing firms to disclose their private information (Healy \& Palepu, 2001). Governance code exists to maintain good governance. That is, to ensure that the firm is governed in accordance to the idea of the shareholders. The codes are largely not mandatory for listed firms (Kollegiet, 2010). In their work, Aguilera and Alvaro (2009) note that most codes have some recommendations on six governance issues: a balance of executive and non-executive directors, such as independent nonexecutive directors; a clear division of responsibilities between the chairman and the chief executive officer; the need for timely and quality information provided to the board; formal and transparent procedures for the appointment of new directors; balanced and understandable financial reporting; and the maintenance of a sound and efficient system of internal control. The international corporate governance network (ICGN), established in 1995 to develop a global corporate governance practices and to facilitate international dialogue on corporate governance issues, contend that it is in the public interest to encourage and enable the owners of corporations to participate in the governance of those of corporations.

Bushman and Smith (2003) point out that corporate governance disclosure is one of the useful tools in assessing the credibility of financial information, as well as in accurately setting expectation and reducing uncertainty concerning the firm's performance. Bushman, Piotroski and Smith (2004) observe that such disclosure also reveals on whom the responsibility for governing the firm rest, the compensation structure and how and where they invest financial resources. According to ACCA (2009), should the governance mechanisms not be disclosed, the firm's stakeholders may not be able to access such information. Klein, Shapiro, and Young (2005) observe that the Board of Directors (BOD) disclosure is viewed as one of the important element corporate governance disclosure. This includes the size of board and its independence. Among the pros of corporate governance disclosure are gained legitimacy, reduced information asymmetry and reduced capital cost (Healy \& Palepu 2001). Larsson (2009) note that in order to be value relevant, it is imperative that the disclosures are credible. 
IIRC (2013c) points out the information needed by stakeholders to make informed decisions. Consequently, disclosures on governance structure affect the reader's view of the credibility of the entire set of disclosures, because it reflects the confidence of the firm's ability to create value through the business model, be transparent and disclose accurate information.

In Kenya, the Capital Markets Act (Cap. 485A) empowers the Capital Markets Authority (CMA) to issue the guidelines on corporate governance. The guidelines issued by CMA were developed in reference to approaches by various jurisdictions across the world. CMA has also facilitated the Private Sector Corporate Governance Trust in Kenya in the development and issuance of the code of best practice for corporate governance in Kenya. The guidelines recognize the role of good governance in corporate performance. CMA expects listed firms to adopt, nurture, and encourage the progression of practices into best practices; it also expects the directors to comply with minimum requirements. Specifically, every listed company is required to disclose, on annual basis, in its annual report, a statement of the directors stating whether the firm is adhering to the corporate guidelines (Ruparelia \& Njuguna, 2016).

The term 'value relevance' points at the relationship between a security's price and a set of corporate report variables (Balachandran \& Mohanram, 2010). The term is said to have been used first by Amir et al. (1993) even though the literature on the value relevance concept dates back to the nineteen sixties with early contributions by Ball and Brown (1968) and Beaver and Dukes (1972). Scott (2003) holds that accounting information is value relevant if it leads investors to revise their beliefs and actions. For a disclosure to be relevant, it must among others, be quick to respond to users' (particularly the investors) needs.

\section{Literature Review}

A number of corporate scandals and corporate governance failures in the 1990/2000s occasioned by fraud and insufficient systems of control raised the question on the credibility of corporations and particularly the governance. While regulators and standard setters have increased the push on firms in regard to governance disclosure as a way remedying this phenomenon, researcher have carried out studies on the ability of corporate governance disclosure to explain or capture information that affects the value of a firm , as measured by the market value of the disclosing firm (Tariq \& Abbas 2013). In a study on corporate governance and the quality of financial analysts' information, Byard, Li and Weintrop (2006) found out that the quality of financial analysts' information about upcoming earnings increases with the quality of corporate governance and concluded that governance quality is positively correlated with the quality of analyst forecasts. This was seen to 
imply that firms with high governance quality produce more reliable and transparent information. In line with this, McKinsey (2002) observes that according to the Global Investor Opinion Survey, more than 50\% of Western European and North American investors look at governance disclosure as being more, or equally, essential as financial issues, that is, profit, performance and growth potential. In a study on the factors influencing corporate governance disclosures, Mallin and Ow-Yong (2012) conclude that in the rest of the world the number is over $80 \%$.

Mingzhu and Khaled (2013) examined the impact of corporate governance on the level of voluntary disclosures of forward-looking statements in the narrative sections of annual reports and whether such statements impact on future earnings. The study focused on large-scale sample of UK (Financial Times Stock Exchange) FTSE All-Share companies for financial years ending within the period January 1996 to December 2007. The study concluded that better corporate governance improves reporting practice and that the forwardlooking statements of well governed firms improve the stock market's ability to anticipate future earnings. This implies that corporate governance disclosures are value relevant.

Ahsan and Istiaq (2008) studied corporate governance and the valuerelevance of accounting information in Australia. The study used board, audit committee and external audit related variables as a proxy for corporate governance. Value-relevance was measured by the adjusted R2 derived from a regression of stock price on earnings and equity book values following Ohlosn's accounting-based valuation framework. The results showed that firms with strong governance structure exhibit higher value-relevance of accounting information. The results further showed that firm-specific economic variables are important determinants of the value-relevance of accounting information.

In a study "Do the Characteristics of the Board of Directors Affect the Value Relevance of Accounting Information?" Mishari, Faisal and Khalid (2015), based on a hypothesis that the characteristics of the board of directors that influence the value relevance of accounting information may be different in developed and less-developed countries, explored the issue in a lessdeveloped country, Kuwait. Using regressions based on Ohlson's (1995) valuation model, the findings revealed that the structure of board had a significant positive relationship with the value relevance of accounting information. In particular, board size and role duality are significantly associated with firm's market value. The results also showed that accounting reports of firms with a smaller board, where the roles of CEO and chairman of the board are split had higher impact on firm's market value. Cross directorships had a positive, though insignificant, relationship with firm's value. The findings were interpreted to mean that the theoretical prediction 
that the characteristics of the board of directors influence market valuation was correct, and therefore this information is value relevant.

Collins, Kwaku and Jo (2011) examined the relative value relevance of shareholder versus stakeholder corporate governance disclosure in South Africa using a sample of 169 listed firms from year 2002 to year 2007, and established that disclosing good corporate governance practices on both shareholders and stakeholders impacts positively on firm value.

Hussain and Hussain (2012) carried out a research on board of directors' characteristics disclosures and value relevance of accounting information in Malaysia in which they used the panel data approach for 270 Malaysian Shariah - compliant companies over the period of three years covering 2007 to 2009 . The study examined the relationship between some boards of directors' characteristics namely the board of directors' size, number of independent non-executive directors in the board, the Chief Executive Officer (CEO) duality and the number of Muslim directors in the board. Some firm's unique attributes, namely, firm's size, leverage, profitability and size of audit firm were regressed in the model as control variables.

Three panel data estimations, that is, Pooled OLS, Fixed and Random effects models were carried out using the Ohlson's (1995) model to study these relationships. The results revealed that the board size does not affect the value relevance of accounting information, since of the two had a negative nonsignificant relationship. In addition, the findings showed that there is a positive but non - significant relationship between the board independency and value relevance of accounting information. The study also concluded that splitting the roles of CEO from that of the board chairman does not increase value relevance of accounting information. The result also revealed that availability of Muslims in board of director did not strongly influence the value relevance of accounting information. The study interpreted these findings to mean that corporate governance disclosure does not affect the value relevance of accounting information.

Catherine (2008) carried out a study on the value-relevance of corporate governance in Australia. The study hypothesized that corporate governance disclosure enhances the value relevance of accounting reporting, that is, it increases the reliance by market on this information to value the firm. The findings revealed that corporate governance disclosure is not valuerelevant in its own right.

In a study on corporate performance, board structure and their determinants in the banking industry in USA, Adams and Mehran (2008) concluded that there are no benefits for having non-executive director dominance on corporate boards. This conclusion concurs with an earlier related study by Belkhir (2006) who studied board structure, ownership structure, and firm performance in the banking industry in the US. Belkhir 
(2006) noted that board composition has no bearing whatsoever on wealth maximisation. This implies that a haphazard selection of executive and nonexecutive board members is of no consequence in the quest for value creation. Some empirical evidence on corporate governance disclosure and the value of firms indicate a positive relationship between the two. However, findings are not consistent across studies. While some indicate a higher value relevance of disclosures for firms with strong governance structures (for example McKinsey, 2002; Mishari, Faisal \& Khalid 2015), some studies do not agree with these findings (for example Adams \& Mehran, 2008; Belkhir, 2006; Catherine 2008; Hussain \& Hussain 2012). The alternative hypothesis for this study states that corporate governance disclosure in the annual reports of listed banks in Kenya is value relevant.

\section{Research Methodology}

This section introduces the econometric estimations model used in this study. Data covering a period of 6 years (from 2010 to 2015) for 10 banks listed on the Nairobi Securities Exchange over the entire period was collected. The average annual market price per share was used as a proxy for value relevance while content analysis was used to derive a quantitative measure of relevance for each corporate governance disclosure. According to Flöstrand and Ström (2006), while financial disclosures are quantitative in nature, nonfinancial disclosures, like the corporate governance disclosure, are qualitative, in text form, and they relate to future expectations and their related effects on creation of value. Consequently, non-financial disclosures are not only hard to identify and standardize, but also to measure or quantify. This fact informed the use of content analysis to derive a quality indicative index.

\section{Content Analysis Process and its Rationale}

Content analysis is defined as any methodological measurement applied to text (or other symbolic materials) for social science purpose (Duriau et al., 2007). Content analysis has been widely applied in accounting research to reveal useful insights into the general mood of disclosures and to quantify the sentiment on various subjects. It is an established approach for gathering data from annual reports (Abeysekera \& Guthrie, 2005; Alves, 2011; Steenkamp \& Northcott, 2007).

Leitoniene and Sapkauskiene (2015), observe that content analysis application on qualitative data can be categorized into two main groups: (a) based on volume, that is, textual analysis (thematic content analysis, that is, the study of clarity and linguistic analysis) and, (b) based on quality, that is, calculation of disclosure index (often presented as evaluation of quality of disclosure). Approaches based on volume do not take into account quality or meaning of the content of a disclosure, but they just focus on the quantity of 
information in a disclosure, for example, the number of pages, sentences or words, phrases, lines and so on. The limitation is that a disclosure can include content that are not of relevance to the subject matter (Chiu \& Wang, 2015).

On the other hand, approaches that are based on the quality aim at evaluating the quality of information in a disclosure using a quality indicative index. Disclosure quality index can be defined as an instrument that is designed to measure a number of indicators, in which when the indicators are summed up to reveal the level of specific information disclosed. The quality indicative index is a practical and research-based tool and it is applied on the basis of guidelines or other indicators that are presented in the disclosure. The researcher need to first employ a coding system. Although this approach can be subjective, it is much more comprehensive and allows a better assessment of the object under investigation, because it takes into account more parameters (Hooks \& Staden, 2011).

The approach used in this study, focused on evaluating the quality of information in corporate governance disclosures. It involved three broad stages: (a) determining the words contained in each of the sample disclosures and their frequency of occurrence (b) generation of relevant words which are related to corporate governance disclosures using a dictionary-based tool (c) determining the aggregate frequency of occurrence of relevant words, which is a quantitative indicator of the quality and level of relevance of a disclosure.

\section{Determining the Words Contained in Sample Disclosures and Their Frequency of Occurrence}

First a total of sixty electronic copies of annual reports (one copy each year, for six years, by ten banks) released by the ten banks covered in this study for the years 2010 to 2015 were uploaded into content analysis specialized software tool Atlas.ti, version 8 . Second, the corporate governance disclosure in each report was coded resulting into sixty data codes. Third, a list of all the words contained in every data code and their frequency of occurrence was generated in the form of an Ms excel output.

\section{Generation of Relevant Words Related to Corporate Governance Disclosure}

In his work "Basis content analysis", Weber (1990) details the application of dictionaries in carrying out content analysis. Dictionaries are previously generated word lists to a certain topic that pre-define the words that will be counted in the content analysis (Vourvachis \& Woodward, 2015). According to Short et al. (2010) most of content analysis studies use dictionary-based tools that may have standard dictionaries already implemented or at least allow their generation. Harvard dictionary was used in this study. 
Harvard dictionary is a famous and frequently used standard dictionary, and it can be used for examining tone and sentiment in corporate disclosure. It is a computer based program that can be used to find words that match a given set of constraints and that should be used in a given context. A wide variety of constraints on meaning, spelling, sound, and vocabulary can be specified in any combination permitting a list of words and phrases relating to a given concept to be generated (Marie-Claude \& Cormier 2014).

This study used a disclosure index developed by Robb et al. (2001), in a study "Nonfinancial disclosures across Anglo-American countries", to generate words from the dictionary. The Robb et al. index is based on the work of the AICPA (The Jenkins report). Relevant words were generated for the following five areas of corporate governance disclosure.

Table 1: Index of Quality of Corporate Governance Disclosure

Index of quality of corporate governance disclosure

- Identity and background of directors and management

- Management activities - meetings and attendances

- The major segments by which management operates the company

- Identity of major shareholders, all shares owned, and by directors, management, and employees

- Division of responsibilities between the chairman and the chief executive officer

\section{Determining the Aggregate Frequency of Relevant Words}

Providing information on a specific topic entails the use of related words more often (see Elo \& Kyngäs, 2007; Rolfe, 2006; Thomas et al., 2014). According to Pennebaker et al. (2003) the words used can transport information, despite of their semantic context. The authors further contend that while verbal language is greatly influenced by non-verbal communication, information that is transmitted in written language is more primarily dependent on the actual word.

Pennebaker et al. (2003), points out that the resulting structure of words, allows a researcher to evaluate different data sources based on their content. On this basis, observation of a distinct group of words in a disclosure can be taken as an indicator of the provision of specific information. Building on this perspective, and in line with prior research that has identified word frequency as a sign for cognitive centrality (see Abrahamson \& Hambrick, 1997; Bailey, 2008; Bengtsson, 2016; Duriau et al., 2007) the aggregate frequency of occurrence of the relevant words (in this study, words used in corporate governance disclosures in annual reports of listed banks, as they appear in the list of the dictionary generated relevant words for corporate governance disclosure) was then taken as a qualitative indicator of the level of relevance for each disclosure. 
The general empirical model used in this study was defined as follows:

$M V_{i}=\beta_{0}+\beta_{1} X_{i}+\varepsilon$

Where:

MV = Market Value of Equity

$\mathrm{X}=$ Corporate governance disclosure

$\beta_{1}=$ the coefficient of $\mathrm{X}_{\mathrm{i}}$ for $\mathrm{i}=0,1 \ldots$

$\varepsilon=$ Random "error" assumed to have a $\mathrm{N}(0, \sigma 2)$ distribution

\section{Results and Discussion}

Both descriptive and inferential analyses were carried out in this study. The results presentation and discussion are presented here.

\section{Descriptive Analysis of Data}

Table 2 presents the summaries of the descriptive statistics of the variables used in this study.

Table 2: Descriptive Statistics of the Study Variables

\begin{tabular}{llcccccc}
\hline & & $\mathbf{2 0 1 0}$ & $\mathbf{2 0 1 1}$ & $\mathbf{2 0 1 2}$ & $\mathbf{2 0 1 3}$ & $\mathbf{2 0 1 4}$ & $\mathbf{2 0 1 5}$ \\
\hline $\begin{array}{l}\text { Corporate } \\
\text { governance } \\
\text { disclosure }\end{array}$ & & & 116.9 & & & & 233.1 \\
& $\begin{array}{l}\text { Mean } \\
\text { Std. }\end{array}$ & 111.20 & 0 & 119.60 & 116.60 & 119.10 & 0 \\
& $\begin{array}{l}\text { Deviation } \\
\text { Minimum }\end{array}$ & 17.34 & 15.56 & 19.41 & 13.24 & 17.93 & 29.98 \\
& 21.00 & 36.00 & 16.00 & 49.00 & 46.00 & 88.00 \\
& & & 187.0 & & & & 380.0 \\
& Maximum & 193.00 & 0 & 208.00 & 173.00 & 214.00 & 0 \\
& & & & & & & \\
& Mean & 52.89 & 51.20 & 77.08 & 96.51 & 77.72 & 57.68 \\
& $\begin{array}{l}\text { Std. } \\
\text { Deviation }\end{array}$ & 18.97 & 20.20 & 28.94 & 33.51 & 26.76 & 21.02 \\
& Minimum & 14.81 & 12.48 & 16.87 & 16.80 & 14.07 & 7.89 \\
& & & 213.8 & & & & 198.8 \\
& Maximum & 204.58 & 3 & 298.45 & 326.85 & 251.48 & 8 \\
\hline
\end{tabular}

In general, the mean for corporate governance disclosure is seen to assume an upward trend. This means that the quality of the disclosure generally improved over the study period. Topazio (2013) observe that there has been a growing importance of financial markets in recent decades which has led to a continuous increase in the demand by the investment community for more comprehensive and timely information to be reported by companies which, according to Stewart (2015) have forced organizations to react to stakeholders' demands and the significance of inclusion of non-financial disclosure have increased cumulatively. The findings reflect the results of a study by Ocean (2015) which concluded that narrative accounting represented 
$84 \%$ of total value market value which represented a growth of $52 \%$ from 1985.

The results also revealed a significant variation in the quality of the disclosure from year to year and from company to company over the period under study. The disclosure had a minimum of 16 and a maximum of 380 . This reflects the observation by Cascino et al. (2013) that the advancement regarding integrated reporting is an ongoing process and that much of this is unregulated and therefore preparers are free to express themselves. This invites impression management occasioning the potential for readers to be treated to particular interpretations and ways of thinking. The agency theory is founded on the idea of maximization of individual advantage, it thus presupposes that the principal and agent are opportunistic and steadily seek out their own self-interest and preferences.

\section{Inferential Statistics Results}

The null hypothesis tested in order to validate data analysis was that corporate social responsibility disclosure in the annual reports of listed banks in Kenya has no value relevance. This section present results of the correlation and regression analysis. Before proceeding with the analysis several diagnostic tests were carried out to test how well the data fitted in the model. The results are presented in Table 3.

Table 3:Diagnostic Tests Results

\begin{tabular}{|c|c|c|c|}
\hline Diagnostic tests & Test used & Criterion & Conclusion \\
\hline $\begin{array}{l}\text { Reliability } \\
\text { Results }\end{array}$ & $\begin{array}{l}\text { Cronbach's } \\
\text { Alpha }\end{array}$ & $\begin{array}{ll}0.70 & \text { or } \\
\text { above }\end{array}$ & Acceptable reliability coefficient of 0.7 \\
\hline Factor Analysis & $\begin{array}{l}\text { Factors } \\
\text { loadings }\end{array}$ & $\begin{array}{l}0.40 \text { or } \\
\text { above }\end{array}$ & The variables had a factor loadings above $40 \%$ \\
\hline Normality Test & $\mathrm{K}-\mathrm{S}$ test & $\mathrm{p}>0.05$ & Data for the variables was normally distributed \\
\hline Multicollinearity & VIF & $\mathrm{VIF}<10.0$ & No threat of multicollinearity \\
\hline $\begin{array}{l}\text { Hausman Test for } \\
\text { Model Specification }\end{array}$ & Hausman Test & $\mathrm{p}>0.05$ & $\begin{array}{l}\text { chi }^{2}=\mathbf{0 . 8 6 7 5} \text {; Null hypothesis that a random } \\
\text { effect model is the best was not rejected }\end{array}$ \\
\hline Homoscedastic Test & $\begin{array}{l}\text { Breusch and } \\
\text { Pagan (1979) }\end{array}$ & $\mathrm{p}>0.05$ & $\begin{array}{l}\text { Null hypothesis was accepted and concluded that } \\
\text { there was homoscedasticity }\end{array}$ \\
\hline Stationarity & $\mathrm{ADF}$ & $\mathrm{p}>0.05$ & $\begin{array}{l}\text { The variables become stationary at first } \\
\text { differencing (unit root disappeared on first } \\
\text { differencing) The null hypothesis that there is a } \\
\text { unit root was subsequently rejected }\end{array}$ \\
\hline
\end{tabular}

\section{Correlation Results}

This section contains results of correlation tests conducted to test the association between of corporate governance disclosure and the average MPS. 
Table 4: Correlation Matrix

\begin{tabular}{llr}
\hline & Correlations & $\begin{array}{c}\text { Corporate governance } \\
\text { disclosure }\end{array}$ \\
\hline $\begin{array}{llr}\text { Corporate governance } \\
\text { disclosure }\end{array}$ & & 1 \\
& Pearson Correlation & \\
Sig. (2-tailed) & 0.441 \\
Average MPS & Pearson Correlation & 0.001 \\
& Sig. (2-tailed) & $\mathbf{6 0}$ \\
\hline
\end{tabular}

The results showed that corporate governance disclosure had a correlation value $r=0.441$ and $p$-value $=0.001$. The finding revealed a strong positive association between corporate governance disclosure and average market price per share. This finding implies that positive change in corporate governance disclosure could bring about a positive response in average market price per share hence the value relevance of annual reports. Bushman and Smith (2003), Healy and Palepu (2001) and Larsson (2009) also pointed out that corporate governance disclosure is one of the useful tools in assessing the credibility of financial information, as well as in accurately setting expectation and reducing uncertainty concerning the firm's performance.

\section{Regression Analysis Results}

Regression analysis was carried out to test the effect of corporate governance disclosure on the average MPS. The Hausman test for model specification showed a prob>chi2 value of 0.8675 which is greater than the critical $\mathrm{p}$ - value at 5\% level of significance. This implies that the null hypothesis that a random effect model is the best was not rejected. The study used random effect regression model to test the relationship between corporate governance disclosure and the average MPS. The findings are presented in Table 5.

Table 5: Corporate Governance Disclosure and Average MPS

\begin{tabular}{lcccc}
\hline \multicolumn{1}{c}{ Average MPS } & Coef. & Std. Err. & $\mathrm{z}$ & $\mathrm{P}>|\mathrm{z}|$ \\
\hline Corporate Governance Disclosure & 0.36921 & 0.154482 & 2.39 & 0.004 \\
constant & 50.17978 & 27.35442 & 1.83 & 0.067 \\
& & & & \\
Wald $\mathrm{chi}^{2}(1)=1.94$ & & & & \\
Prob $>\mathrm{chi}^{2}=0.1640$ & & & & \\
R-squared $=0.0155$ & & & & \\
\hline
\end{tabular}

The findings revealed a Wald $\mathrm{chi}^{2}=1.94$ and $\mathrm{Prob}>\mathrm{chi}^{2}=0.0155$. This imply that the model average MPS $=50.17978+0.36921$ (Corporate Governance Disclosure) $+\varepsilon$ was statistically significant. The findings further 
revealed that $\mathrm{R}$-squared $=0.0155$, meaning that $1.55 \%$ of the variation in the average MPS was accounted for by corporate governance disclosure. The results of the beta coefficient of the resulting model showed that the constant $\alpha=50.17978$ was significantly different from 0 , since the $\mathrm{p}$ - value of 0.067 was greater than 0.05 . The coefficient $\beta=0.36921$ was also significantly different from 0 with a p-value of 0.004 which was less than 0.05 . The results imply that a unit change in corporate governance disclosure will bring about 0.36921 units change in average market price per share. This confirms that there is a significant positive relationship between corporate governance disclosure and average market price per share for the listed bank in Kenya.

The finding agrees with those of (Bushman \& Smith, 2003; Healy and Palepu, 2001; Larsson, 2009) who also pointed out that corporate governance disclosure is one of the useful tools in assessing the credibility of financial information, as well as in accurately setting expectation and reducing uncertainty concerning the firm's performance. The findings further correspond with a report by IIRC (2013c). The report pointed out the information needed by stakeholders to make informed decisions and concluded that disclosures on governance structure affect the reader's view of the credibility of the entire set of disclosures, because it reflects the confidence of the firm's ability to create value through the business model, be transparent and disclose accurate information.

\section{Summary of Findings}

The descriptive results showed that a change in corporate governance disclosure resulted in a similar change the market price per share. The correlation test findings indicated a strong positive association between corporate governance disclosure and average market price of shares. These results implied that positive change in corporate governance disclosure in annual reports could lead to a positive change in average market price per share. Regression analysis result revealed that there is a significant positive relationship between corporate governance disclosure in annual reports of the listed bank in Kenya and the average MPS. The findings showed that the corporate governance disclosure in annual reports of the listed bank in Kenya is value relevant.

\section{Conclusion}

The study further found out that corporate governance disclosure in annual reports of listed banks in Kenya is value relevant and therefore concluded that corporate governance disclosure is essential for decisions on investment in the share of listed banks in Kenya. In this case corporate governance disclosure will enhance the public confidence in investing in 
the organization. Therefore it is important for listed firms to disclose relevant information regarding the corporate governance.

\section{Recommendations}

The study observed significant explanatory power of corporate governance disclosure on the average MPS. In extension, this means that narrative accounting is important for decisions on investment in shares of firm. The study therefore recommends an expanded role of the auditor in reviewing and reporting non-financial disclosures. Currently in accounting reporting, under ISA 720 (the auditor's responsibilities relating to other information in documents containing audited financial statements), the auditor is not obligated to formally audit and report on non-financial disclosures. Instead, an auditor reviews the accounting narratives to ascertain if the narratives are consistent with the financial statements. The study further recommends more guidelines and regulations in relation to non-financial disclosures to ensure that firms put clearer and relevant information in the hand of investors.

\section{References:}

1. Abeysekera, I., \& Guthrie, J. (2005). An empirical investigation of annual reporting trends of intellectual capital in Sri Lanka. Critical Perspectives on Accounting , 16 (3), 151-163.

2. Abrahamson, E., \& Hambrick, D. (1997). Attentional homogeneity in industries: the effect of discretion. Journal of Organizational Behavior , 18, 513-532.

3. ACCA. (2009). Disclosures on corporate governance, reporting trilogy. Retrieved from http://www.accaglobal

4. Adams, R., \& Mehran, H. (2008). Corporate performance, board structure and their determinants in the banking industry. New York, NY: Federal Reserve Bank of New York.

5. Aguilera, R., \& Alvaro, C. (2009). Codes of Good Governance. Corporate Governance:An International Review, 376-387.

6. Ahsan, H., \& Istiaq, A. (2008). Corporate governance and the valuerelevance of accounting information: Evidence from Australia. Accounting Research Journal , 21, 167-194.

7. Alves, M. (2011). Content Analysis: Its Use in Accounting Publications. Revista Universo Contábil , (7) 3, 146-166.

8. Amir, E., \& Lev, B. (1996). Value-relevance of nonfinancial information: the wireless communications industry. Journal of Accounting \& Economics , 22, 3-30.

9. Amir, E., Harris, T. S., \& Venuti, E. K. (1993). A Comparison of the Value- Relevance of U.S. Versus Non-U.S. GAAP Accounting 
Measures Using Form 20-F Reconciliations. Journal of Accounting Research, 31, 230-264.

10. Bailey, J. (2008). First steps in qualitative data analysis: transcribing. Family Practice , 25, 127-131.

11. Balachandran, S., \& Mohanram, P. (2010). Is the decline in the value relevance of accounting driven by increased conservatism? . Review of Accounting Studies, forthcoming .

12. Ball, R., \& Brown, P. (1968). An empirical evaluation of accounting income numbers. Journal of Accounting Research , 6 (2), 159-178.

13. Beaver, H., \& Dukes. (1972). Interperiod tax allocation earnings expectations and the behavior of security prices. Accounting Review, 47: 320-418.

14. Belkhir, M. (2006). Board structure, ownership structure, and firm performance: evidence from banking. Orle'ans: Laboratoire d'Economie d'Orle'ans.

15. Bengtsson, M. (2016). How to plan and perform a qualitative study using content analysis. Elsevier - NursingPlus Open 2, 8-14.

16. Bushman, R., \& Smith, A. (2003). Transparency, financial accounting information and corporate governance. Federal Reserve Bank of New York Economic Policy Review , 65-87.

17. Bushman, R., Piotroski, J., \& Smith, A. (2004). What determines corporate transparency. Journal of Accounting Research , 42 (2), 20752.

18. Byard, D., Li, Y., \& Weintrop, J. (2006). Corporate governance and the quality of financial analysts' information. Journal of Accounting and Public Policy, 609-625.

19. Cascino, S., Clatworthy, M., Garcia Osma, B., Gassen, J., Imam, S., \& Jeanjean, T. (2013). The Use of Information by Capital Providers: Academic Literature Review. Edinburgh: The Institute of Chartered Accountants of Scotland and the European Financial Reporting Advisory Group.

20. Catherine, W. (2008). The Value-Relevance of Corporate Governance: Australian Evidence. Corporate Ownership \& Control , 6, 292-300.

21. Chiu, T., \& Wang, Y. (2015). Determinants of social disclosure quality in Taiwan: an application of stakeholder theory. Journal of Business Ethics , 129 (2), 379-398.

22. Collins, G. N., Kwaku, K. O., \& Jo, D. (2011). The Relative Value Relevance of Shareholder versus Stakeholder Corporate Governance Disclosure Policy Reforms in South Africa. 23 (6), 550-560.

23. Duriau, V., Reger, R., \& Pfarrer, M. (2007). A Content Analysis of the Content Analysis Literature in Organization Studies: Research 
Themes, Data Sources, and Methodological Refinements, Organizational Research Methods. Sage publications.

24. Elo, S., \& Kyngäs, H. (2007). The qualitative content analysis process. Journal ofAdvanced Nursing , 62 (1), 107-115.

25. Flöstrand, P., \& Ström, N. (2006). The valuation relevance of nonfinancial information. Management Research News , 29 (9), 580-597.

26. Healy, P., \& Palepu, G. (2001). Information asymmetry, corporate disclosure, and the capital market: a review of the empirical disclosure literature. Journal of Accounting and Economics , 31 (1), 405-40.

27. Hooks, J., \& Staden, V. (2011). Evaluating environmental disclosures: The relationship between quality and extent measures. The British Accounting Review , 43, 200-213.

28. Hussain, K., \& Hussain, A. (2012). Board of Directors' Characteristics and Value Relevance of Accounting Information in Malaysian Shariah - Compliant Companies: A Panel Data Analysis. Economics and Finance Review , 2 (6), 31-44.

29. IASB. (2011). International Accounting Standard 1.

30. IIRC. (2013c). Value creation - Background paper. Retrieved from http://www.theiirc.org/resources/frameworkdevelopment/background-papers

31. Klein, P., Shapiro, D., \& Young, J. (2005). Corporate governance, family ownership and firm value: the Canadian evidence. Corporate Governance , 13 (6), 769-784.

32. Kollegiet, F. (2010). Svensk kod för bolagsstyrning. Retrieved from http://www.corporategovernanceboard.se

33. Larsson, L. (2009). Hållbar affärsutveckling. Stockholm: FAR SRS Förlag AB.

34. Leitoniene, S., \& Sapkauskiene, A. (2015). Quality of Corporate Social Responsibility Information. 20th International Scientific Conference Economics and Management, (pp. 334 - 339).

35. Mallin, C., \& Ow-Yong, K. (2012). Factors influencing corporate governance disclosures: evidence from Alternative Investment Market (AIM) companies in the UK. The European Journal of Finance , 515533.

36. Marie-Claude, L., \& Cormier, C. (2014). Dictionaries and the Digital Revolution: A Focus on Users and Lexical Databases. International Journal of Lexicography, 27, 331-340.

37. McKinsey. (2002). Global Investor Opinion Survey: Key findings. Retrieved from http://www.eiod.org/uploads/Publications/Pdf/II-Rp4-1.pdf 
38. Mingzhu, W., \& Khaled, H. (2013). Voluntary forward-looking statements driven by corporate governance and their value relevance. Journal of Accounting and Public Policy , 32 (3), 26-49.

39. Mishari, M. A., Faisal, S. A., \& Khalid, A. A. (2015). Do the characteristics of the board of directors affect the value relevance of accounting information? International Journal of Accounting and Finance , 5 (2), 255-266.

40. O’Regan, P. (2008). Financial Information Analysis. John Wiley \& Sons Ltd.

41. Ocean, T. (2015). Intangible Asset Market Value. Chicago: Ocean.

42. Ohlson, J. A. (1995). Earnings, book value and dividends in equity valuation. Contemporary Accounting Research, 11, . 661-687.

43. Pennebaker, J., Mehl, M., \& Niederhoffer, K. (2003). Psychological Aspects of Natural Language Use: Our Words, Our Selves. Annual Review of Psychology, 54, 547-577.

44. Robb, S. W., Single, L. E., \& Zarzeski, M. (2001). Nonfinancial disclosures across Anglo- American countries. Journal of International Accounting, Auditing and Taxation , 71-83.

45. Rolfe, G. (2006). Validity, trustworthiness and rigour: quality and the idea of qualitative research. Journal of Advanced Nursing , 53, 304310.

46. Ronnie, L. (2009). Voluntary corporate governance disclosure, firm valuation and dividend payout: evidence from Hong Kong listed firms. Unpublished Ph.D. dissertation.

47. Ruparelia, N., \& Njuguna, A. (2016). The Evolution of Corporate Governance and Consequent Domestication in Kenya. International Journal of Business and Social Science, 7, 153-163.

48. Scott, W. (2003). Financial Accounting Theory. Toronto, Canada: Prentice Hall.

49. Short, J., Broberg, J., Cogliser, C., \& Brigham, K. (2010). Construct validation using computer-aided text analysis (CATA): An illustration using entrepreneurial orientation. Organizational Research Methods, 13, 320-347.

50. Steenkamp, N., \& Northcott, D. (2007). Content Analysis in Accounting Research: the Practical Challenges. Australian Accounting Review , 16 (2), 166-195.

51. Stewart, L. (2015). Understanding Corporate Performance: Investor Demand for ESG Standards, Executive Summary. Journal of Applied Corporate Finance , 27 (2), 5-6.

52. Tariq, Y., \& Abbas, Z. (2013). Compliance and multidimensional firm performance: Evaluating the efficacy of rule-based code of corporate governance. Economic Modelling , 565-575. 
53. Thomas, B., Céline, B., \& Ludwig, M. (2014). Advancing ValueRelevance Studies on Non-Financial Information: A Complementary Approach. University of St.Gallen, Switzerland.

54. Topazio, N. (2013). Consultation Draft of the International integrated reporting. Chartered Institute of Management Accountants .

55. Vourvachis, P., \& Woodward, T. (2015). Content analysis in social and environmental reporting research: trends and challenges. Journal of Applied Accounting Research , 16, 166-195.

56. Weber, R. (1990). Basis content analysis . Thousand Oaks: Sage Publications.

57. Weygandt, J., Kieso, D., \& Kimmel, P. (2003). Financial accounting (UOPHX special edition series). New York: John Wily and Sons. 